\title{
Teaching Reading Skills in Home Language: A Case Study of Foundation Phase Teachers
}

\author{
Masello Phajane \\ Department of Early Childhood Education, University of South Africa \\ phajamh@unisa.ac.za \\ Matseliso L Mokhele
}

Department of Curriculum and Instructional Studies, University of South Africa

\section{Doi:10.5901/mjss.2013.v4n3p463}

\section{Abstract}

Foundation phase teachers are the beginning and the foundation of it all. Teachers of foundation phase should be commended for being eye openers. They start learners from scratch and teach them the basics of reading. But research has shown that most foundation phase teachers are uncertain about the methods and approaches that they need to use in order to teach reading to the beginners at schools. Admittedly, some teachers have developed methods of their own that are far superior to any that have been investigated and commercially published. It is therefore imperative to understand the different ways that teachers employ to engage children when they start to teach them reading and how they help them gain literacy as the first step in the empowerment of the mind. This study is qualitative in nature and it examines methods used by foundation phase teachers in teaching the grade ones reading Setswana. Data for this paper was collected data from 8 different foundation phase schools in Bojanala District at Brits which falls under the Department of Basic Education (DBE). In this study, four foundation phase teachers were observed and subsequently interviewed on the methods that they use when they teaching Setswana to the foundation phase learners. The teaching of Setswana involved teaching the learners to read. While they are four teachers observed, this paper will, however, focus on two teachers only. In the end it was clear that more cooperation and collaboration between teachers and local circuit and district administrators in planning and delivering teaching approaches and the workshops. Teachers and local administrators need to keep abreast with new developments in the fields of language and literacy development in order to effectively challenge and critique new approaches. Finally, teachers should also be supported by the Department of Basic Education in conducting investigation on teaching and learning in their classrooms.

\section{Introduction}

Reading is a foundational skill that all children need if they are to succeed in life. As one of the four language skills in which learners need to be versed in their earliest years in formal schooling, reading builds the foundation for all formal learning in school (Teale 2003:114). If learners do not acquire this skill in the foundation phase they will struggle to catch on, even with the help of remedial teaching, and will not progress at school. This study draws on the perspectives of first grade teachers who teach reading at foundation phase in Setswana. It is indeed true that reading forms the basis of all language skills, particularly writing, because the ability to write depends on the ability to read, and what is written can only be meaningful if it can be read (Stahl 2004:57). Therefore, reading and writing are mutually supportive, essential to success in any society and so highly valued and important for both social and economic advancement.

Generally, reading problems are endemic in South Africa. And as late as two years back, there have been "recent media reports on the high matriculation (matric) failure rate indicating that most learners still cannot read or write and thus bring down the overall matric performance" (Department of Basic Education 2010:30). There has also been a report of cases in which learners in higher grades continue to battle to read and write, even to write their names (Barone 2005:47). The frustration shared by many senior phase teachers suggests problems at the foundation phase, with the inability to read and write identified as one of the major causes of poor academic performance of learners across the country (Johnson 2006:25). The research available indicates that, in general, South African learners' reading skills are poorly developed from primary schools through to tertiary level (McDonald 2002:47). Surprisingly, our government has only recently become aware that children cannot read, and that part of the problem applies to the mother tongue and first additional language. It is also apparent that teachers do not have the capacity to teach reading and writing. 
In any country, the initial years of schooling (foundation phase) are critical, because that is the time when learning in general, and reading skills and habits in particular, are developed. When children experience success in effectively using these skills they become interested in and excited by reading, which enables them to have a level of literacy and numeracy by the time they start formal schooling (Read Educational Trust 2005:12). Research has shown that learners who learn how to read and write at an early stage cope well and perform better academically (Early Reading Strategy panel 2003:22). This paper examines the methods used by foundation phase teachers in the teaching of reading of Setswana as home language $(\mathrm{HL})$ to school beginners (Grade 1 learners).

\section{Literature review - concept of reading}

There is a worldwide concern about the increasing rate of learners exhibiting reading difficulties and therefore a fundamental effort toward improving reading skills has been initiated at both international and national levels, (Lessing \& De Witt 2005:242-257). A number of key educational milestones have been set out in the development of reading in South Africa.

In the past it was generally believed that children should not be taught to read before they came to school, as it was seen to need special instruction that only teachers could provide. However, recent research has shown that many children learn to read by themselves, just by being exposed to books from an early age, listening to stories and seeing people around them reading and writing. Slowly they learn to interpret pictures, recognise words and make connections between the two, a gradual process termed "emergent reading" (Cooper 2005:4).

According to Pretorius and Machet (2004:33), cultivating good readers involves focussing on strategies that teachers can use to teach children to read effectively. The teacher, especially in the lower grades of schooling, must consider the following aspects:

\section{Phonics instruction}

Phonics instruction teaches children that there is a relationship between the letters of written language (graphemes) and the individual sounds of spoken language (phonemes). Contrary to the views of some critics, for example, Graves, Juel and Graves (2007:21), according to Rose (2006:27) the goal of phonics instruction is to make children understand that there is a systematic and predictable relationship between written letters and spoken sounds. Knowing these relationships will help children recognise familiar words accurately and automatically, and to decode new ones. A child must learn phonic information to the point of it becoming automatic, thus contributing to his or her ability to read words in isolation and in connected text. However, the phonics instruction is a means to an end, not an end in itself (Rose 2006:31). Stahl (2004:35), using language borrowed from Durkin, defines phonics as "any approach in which the teacher does or says something to help children learn how to decode words". There are numerous approaches to teaching phonics, but these can be classified into two broad groups, analytic and synthetic (Stahl 2004:57). The synthetic approaches begin with learning letter sound relationships and blending them to create words c/a/t then cat (Bald 2007:18). The synthetic phonics approach has the learner sound out and blend letters to form words, one Setswana example of the same is: s-e-k-o-l-o then sekolo, from parts to the whole.

\section{Phonological awareness}

Phonological awareness is hearing and understanding the different sounds and patterns of spoken language, and includes the different ways oral language can be broken down into individual parts, for instance, separate sounds and syllables. For some children, hearing these different parts of spoken language can be difficult, because it requires them to attend to the sounds of speech separately from meaning (Ma \& Crocker 2007:53). Phonics means decoding a word by breaking it down into units (syllables and letters), and phonics instruction teaches children the relationship between the letters of written language and individual sounds of spoken language. Knowing this relationship teaches children to read and write words. For Gray \& McCutchen (2006:325), phonemes are the smallest parts of sounds in a spoken word, for example, in the word "hat" (kuane) the letter $\mathbf{h}(\mathbf{k})$ represents the sound huh (ku), and in phonics there is a link between the sound and the letter. Each sound can be written as a letter or group of letters, e.g., the "buh" (bu) sound is written as "b" (b). 


\section{Vocabulary instruction}

If one accepts that comprehension is the goal of reading then vocabulary is the foundation of reading comprehension, referring to the body of words one needs to communicate effectively. This includes knowing the meaning of the words and how to pronounce them correctly. If a learner has a limited understanding of vocabulary he or she will have a limited understanding of the concepts, which in turn will limit the understanding of the content. As beginners in reading, children have to make sense out of words they see in print. Educational researchers Raphael, Pardo \& Highfield (2002:107) believe that there is a strong correlation between reading and vocabulary knowledge, meaning learners who have a large vocabulary are usually good readers. Vocabulary can also be learned incidentally during storybook reading or when listening to others. It is true that if one reads extensively one is likely to be or become a good reader. Children also need to recognise the shape of words and the letters and syllables that make up the words (Stahl 2004:63).

\section{Fluency instruction}

Fluency is the ability to read orally with speed, accuracy and proper expression. Fluency is important because it provides a bridge between word recognition and comprehension, and can be achieved through repeated oral reading with teachers, peers or parents. Feedback is essential to learners, whether or not their reading is as expected, and they should be encouraged to read silently on their own at school and at home. The more children read the more their reading skills will improve and the more their world view broaden (Morrow 2005:23-24).

\section{The alphabetic principle}

The alphabetic principle is by far the most debated area in beginning reading. These debates have a rich history, with many seminal publications attempting to resolve them (Adams 1990:81; Chall 1987:81, as cited in NRP 2000:81). The heart of the debate has usually centred around which method (e.g. phonics) is best for teaching the alphabet principles, or on the sequence of that teaching (e.g. before formal reading instruction). However, arguably, most would agree that the alphabetic principle is an integral part of beginning reading, that is, the notion of how sounds map onto print is essential in reading. In terms of the reciprocity of beginning reading, knowledge of the alphabetic principle is necessary to learn to read, yet this knowledge is also strengthened as children begin to read (National Literacy Trust 2006:4).

\section{Making a word}

According to Allington (2002:84), the teacher gives all the children the magnetic letters or letter cards, $\mathbf{a}, \mathbf{t}, \mathbf{p}, \mathbf{s}$, and $\mathbf{b}$.

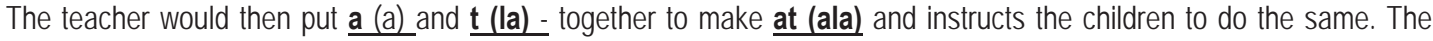
teacher then models placing $\underline{\mathbf{b}(\mathbf{b})}$ at the beginning of the word at (ala) to make bat (bala). S/he next asks the children to replace the $\underline{\mathbf{b}}$ with a $\underline{\mathbf{p}}$ to make pat (pala) and then to reverse the $\underline{\mathbf{t}}$ and $\mathbf{p}$ to make tap (lapa). The lesson continues with the teacher modelling many words, eventually increasing the number of letters in the words. The children are also provided with opportunities to make their own words.

\section{Blending as part of reading skills}

According to McCutchen (2002:69) and Snow (2002:5-6), when reading, children need to understand the meaning of the words. Before they can do this, however, they have to be able to work out what the words mean. The phonic skill for this is to look at the letters, say the sounds and hear the word, a process known as "blending" that is saying the sounds in a word and then naming them together to make the word, for example: c-a-t (k-a-t-s-e) is cat (katse). It is a technique the child will need to learn and it improves with practice, though some take longer to do this than others. To begin with, one should sound out the word and see if the child can hear it. The sounds must be said quickly to hear the word and it is easier if the first sound is slightly louder, e. g. b-u-s (b-e-s-e).

\section{Research methodology}

This research is positioned as a qualitative case study, and according to De Vos, Delport; Fouche and Strydom (2006:34), it meets the interpretive researcher's purpose of understanding situations that are complex. This research is 
based on the information collected at schools that are complex networks in which staff members interact at various levels. Levin \& Rock (2003:43) are of the opinion that interpretive social research emphasises the complexity of human beings, and attempts to construct and understand their worlds. As mentioned before, the researchers of this paper collected data from 8 foundation phase schools in Bojanala District at Brits. Four teachers were observed and were later interviewed on the teaching of beginning reading. In order to establish how the research was approached, observations and interviews and were used to collect many views. For the purpose of this paper, only two teacher case studies from two different schools will be reviewed.

\section{Findings and discussions}

Mpho and Thato are the foundation phase teachers teaching reading in Setswana in two different schools. The teachers' profiles are tabled below:

\begin{tabular}{|c|c|c|c|c|}
\hline Names & Gender & Teaching experience & Age & Home language \\
\hline Mpho & Female & 30 & 52 & Setswana \\
\hline Thato & Female & 27 & 50 & Northern Sotho \\
\hline
\end{tabular}

\section{Case study one: Teacher Mpho}

\subsection{Methods used to teach mother tongue}

The observation began with the researchers trying to establish what methods are used by Mpho to introduce or teach beginning reading in Grade 1. Mpho was asked to explain the methods that she used in her teaching of reading. In her response, she indicated that for the first three months learners are placed in the school readiness class, before a breakthrough to literacy in Setswana could be taught. Mpho explained that this is done because most learners come to foundation phase before they could even know how to write. According to Mpho school readiness programme is a must! Mpho believes that there many advantages of this programme:

Teachers can hardly manage without school readiness programme. Experience has shown that even if things go well without it, but those learners would not be the same as those who would have attended the school readiness programme. The main benefit of this programme is that it helps strengthen the hands of learners and they can be ready at least before they start formal schooling - to use their hands to write something.

Mpho also highlighted that she personally likes the school readiness programme because of the difference it makes in her learners. When a foundation phase teacher is satisfied that learners are ready to read, she introduces them to the breakthrough programme, which is the next phase in the moulding of a learner. Mpho also mentioned that the method she used would be that, a learner would come up with a sentence and she would then use that sentence as a starting point and start asking learners questions about the pictures that they see and narrate a story, (e.g. lesea le a lela). This would all be part of stage 1 in the phase of reading.

While in Mpho's class we also observed that she had a Molteno kit (materials and equipment) in her class, consisting of the teacher's sentence maker and word cards, the teacher's sentence holder, the learner's sentence maker and word cards, the learner's sentence holder, the learner' storybook, the word store, the conversation posters, the phonic frieze posters and the breakthrough Molteno readers. The programme she used would be regarded as the breakthrough to literacy, which prioritises what the learners brings with them to school from home, and is a mother tongue literacy course (The Molteno Project 2003:2).

The advantage of using this programme was that it is a learner-centred method that uses the learner's firsthand experiences and natural interests as motivating forces in helping them to acquire reading skills, (Molteno Project 2003:28). Breakthrough to literacy has several unique features, for example, the teacher taught reading to a group of learners from a poster in the teaching corner, while the other groups were given tasks to occupy them. In the teaching corner the teacher teaches the learners the key sentence for the day from a chart or poster.

After Mpho had talked about the sentence, shown it to the learners, on the board and on flashcards, she constructed the sentence she had written on the board from individual letters on flashcards by sticking them on the sentence maker. After the demonstration and after the learners had mastered it, Mpho then gave them each sentence makers and started identifying the words that built the sentence they had covered with her in the teaching corner. In her discussion of breakthrough programme, Mpho states as follows: 
In the breakthrough programme, the learner does not only read the word on the board but he or she is also able to touch the word on the flashcard. The learner can turn it sideways, upside down and anyhow at any time because he or she has access to it, everyday, at anytime! The learner is able to construct and remove the word as he or she wishes, she creates the one she or he likes. In this approach, the learner thinks for himself. The teacher simply gives them a word and asks them to write a sentence. They all come up with different sentences. In this approach, control goes to the learner. You, as a teacher, are only there as a guide or a facilitator.

Mpho felt that learners would need to attend the school readiness programme before they could even begin to be introduced to the breakthrough approach. She indicated that the reason for this i that predictably, most learners would not know how to write when they first enter school. And this is exactly what she said:

So the schools readiness programme is part of schooling - it is a must! Experience has shown that even if things go well without it, but those learners would not be the same as those who would have attended the school readiness programme. The main benefit of this programme is that it helps strengthen the hands of learners and they can be ready at least before they start formal schooling - to use their hands to write something.

\subsection{Teacher-learner interaction}

While they were still attending the reading lesson for the class, the researchers also observed, and also taught reading to a group of learners from a conversation poster as a story to the whole class. The teacher, Mpho, discussed with the learners what they thought was happening in the picture and involved their prior knowledge and experiences. The main aim was to get a key sentence from them, using some of the following key words from the the Teachers' Manual. These are the thirteen words (mme (mother), lesea (baby), sekolo (school), mogolo (elderly), robala (sleep), tsoga (wake up), lela (cry), batla (want), ntate (father), ausi (sister), opela (sing), abuti (brother), bona (see), and also seven isolated morphemes (outside prefixes) ; o, le, ka, se, mo, e, a. These were only taught in stage 1.

Once the key sentence had been identified or given, for example: lesea le a lela (the baby is crying), Mpho asked all the learners to repeat the sentence after her. In the process they were identifying different words that made up the sentence. For instance, in the sentence "ntate o bona mme" (father sees mother), she used her finger to distinguish words such as "ntate" (one), "o" (two), "bona" (three), and mme (four). She then asked, "Do you see spaces in between words?" (as represented by her fingers in the demonstration), stressing the spacing from the beginning. Learners learnt about the different sentence parts before they could even they could even write them down. Mpho emphasised to the researchers that the method that she used instil in the learners' heads at an early stage that certain Setswana words are written separately, just as they come out of the mouth in speech.

\subsection{Lesson activities and methods}

All stage 1 words mentioned above were left in the learners' sentence makers after stage 1 evaluation test. Mpho also mentioned that if a learner gets 10-20 words correct, he or she should be given 20 more words of stage 1 in an envelope and be asked to match them with his or her sentence maker. This learner would then have to proceed to stage 2 where he or she would be encouraged to make sentences of his or her own.

Mpho indicated that once the learners has a sound vocabulary of about ten words, simple sentence construction can commence (e.g. ke bona mme), (I see mother), and (ke rata ntate wa me), (I love my father). Simple sentences were read with the children daily and these were also given to the learners as homework. Mpho's approach to the teaching of reading corresponds with the predictable and sequential stages of language development as described by Hough \& Home (2001:47). Since most of her experience was in teaching grade one learners, she had clearly mapped out a systematic way in which to build up the vocabulary of the learners. She built the vocabulary to a level where the learners were able to read a basic reader. Her associating the breakthrough method to flashcards is supported by International Reading Association (IRA) (2002:16), as flashcards with individual words written on them are used for this method, often accompanied by a related picture.

In stage 2, every lesson started with phonics and the teacher would keep the phonics for the compilation of the class dictionary. Stage 3, was the last stage of the breakthrough course, the emphasis in this stage being on communication, which would generally be both oral and written. In the third stage, teachers would have to provide learners with self-made books to compile their own dictionaries, beginning with words in the sentence makers, and they would also be expected to write in paragraphs using punctuation marks. 


\section{Case study two - Teacher Thato}

\subsection{Methods used to teach mother tongue}

Unlike Mpho in case study one, Thato highlighted that Grade 1 learners in her school would be placed in the school readiness programme for the first 12 weeks (i.e. from January to March), learning through play, and then she prepared formal instruction in reading using the sentence method. Thato introduced beginning reading by sequencing vowels and consonants in a step by step format called the traditional method. According to Teale (2003:117) the traditional method emphasised phonemic awareness, phonics and alphabetic knowledge. It is the approach used to teach beginning reading development in the sense that it considers the learner's emergent literacy and gives attention to phonics. She taught reading to beginners by introducing a school readiness programme to all learners during the first three months in her class. She started with vowels, $\mathbf{a}, \mathbf{e}, \mathbf{i}, \mathbf{0}, \mathbf{u}$, and the letter of the alphabets, then formal texts, such as distinguishing colours, matching and transcribing words on flashcards, after which they copied them into their workbooks.

Thato used these activities as part of determining learners who were ready for formal instruction and reading. Those who could accurately recognise the words and read them aloud when accompanied by pictures were then grouped as ready. For her, reading words was the key to reading for learners who were ready for formal work. She explained that the sentence method would grow out of the activities that had been done in the school readiness programme during the first quarter. Those learners who were ready were then assigned to different grade one classes and teachers began formal instruction in reading and other grade one work. Those who were not ready formed a class called the "bridging period", which continued with the school programme for the whole year. The description presented Thato's reflections of teaching beginning reading using the traditional method by first using giant pictures, then flashcards, then sentence strips and then finishing by using of the book. This was how she introduced reading in the first year. Her description of introducing beginning reading started with parts and moved to the whole.

These descriptions were also similar to the traditional method described by Ntsime (1988) in the reader series Mathasedi (The rays of the morning sun), and Buisa o kwale Setswana (Read and Write Setswana) by Mampe, both series for the first grade. In these readers, the traditional method emphasised that the teacher must teach sounds and letters in isolation, then form words and sentences, and finally read a book. Thato recognised the goal of traditional method and the importance of involving learners in reading.

\subsection{Learner interaction}

In her presentation of the lesson, Thato started by telling a story, with all learners sitting on a mat. She did not read them the story directly from the book or even model reading for them. Then she started off by asking them to say the title of the story out loud, and then talked about the pictures in the book by describing the content of the pictures. Thato then began reading aloud the first page and asked questions such as; "what is this?" (ke eng se?), "what is the meaning of this word?" (lefoko le le raya eng?), "what is the duck doing?" (pidibidi e dira eng?) after which the learners would repeat the words on the first page aloud to the rest of the class. If anyone could not pronounce the words in the sentence she helped them. Thato also asked questions about the progress of the story, the learners' prior knowledge on the subject of the book, using the pictures as clues, for example "what's going to happen next?" (go ya go diragala eng?) and about the learner's existing knowledge about events in the story. They continued in this manner until the last page of the book.

Thato told the learners the title of the lesson and explained new words to the learners by using flashcards and the chalkboard. Examples of these new words were: "pidibidi" (duck), "sesa" (swim). She explained the meaning of all the new and unfamiliar words and pronounced them for the class. She then let the class, as a group, repeat the words after her aloud, and ask them one by one to read back the words to her aloud. If the learners had difficulty with the pronunciation she corrected them.

\subsection{Lesson activities and methods}

During the researchers' observation, Mpho drew a picture and had sets of sentence cards, based on the first set of core vocabulary, (ngaka, ngakeng, ngapa, ngala, mosimane, bobola, leboga). On each sentence card she wrote one sentence made up of the core vocabulary. She prepared sentences which were the same as the key sentence taught in the teaching group, with the same core vocabulary used, but in different combinations. She prepared sentences for which 
learners could draw a picture, for example, ke bona ngaka; re mo isa ngakeng; ngaka e a leboga; 0 a re ngapa, mosimane $o$ a ngala. Each learner in a group received a sentence card and read it, drew a suitable illustration for the sentence card in their activity books and copied the sentence from the sentence card into their activity books. After they completed the given sentence card, they chose another and did the same thing, this activity was done by individual learners. She then spent most of the time working with those who needed assistance.

\section{Conclusion}

In conclusion, the researchers would humbly recommend that suitable approaches and methods of teaching reading to beginners should be developed and be included in the curriculum for teacher training. Higher education institutions responsible for teacher training should empower teachers in training to generate teacher-authored reading approaches and methods to be used. This paper therefore further recommends that there should be more collaboration between teachers and district administrators when the planning and the delivering of teaching approaches and courses take place. Teachers and subject specialists need to keep abreast of new developments in the field of language and literacy development in order to effectively challenge and critique new approaches. They should also be supported in carrying out investigations into teaching and learning in their classrooms.

In order to improve the situation it is also recommended that there should be a drawing up of syllabi of methods or approaches of teaching beginning reading in all languages, specifically Setswana in the foundation phase, leading to the advantage that teaching beginning reading methods would be taken more seriously than it is currently. This would also help to narrow the gap between same-level learners at different schools, in terms of the indicators of the exposure to teaching reading methods to beginners. It would minimise the chances of learners transferring from one school to another being at different levels in terms of these indicators.

\section{References}

Allington, RL 2002. Big brother and the national reading curriculum: How ideology trumped evidence. Portsmouth, NH: Heinemann.

Bald, J 2007. Using phonics to teach reading and spelling. London: Paul Chapman.

Barone, DM, Mallette, MH \& Hong Xu S 2005. Teaching early literacy Development, assessment, and instruction. London: The Guilford Press.

Cooper PM 2005. Literacy learning and pedagogical purpose in Vivian Paley's "storytelling curriculum". Journal of Early Childhood Literacy, 5(3):229-251.

Department of Basic Education (DBE) 2010. Curriculum and Assessment Policy Statement (CAPS). Pretoria: DBE.

De Vos, AS, Strydom H CB \& Delport CSL (eds.) 2006. Research at grassroots. Pretoria: Van Schaick.

Early Reading Strategy 2003. The Report of the Expert Panel on Early Reading in Ontario.

Graves MF, Juel C, Dykstra, \& Graves B.B 2007. Teaching reading in the 21st century. New York: Scholastic and Pearson Education.

Gray A \& McCutchen D 2006. Young readers' use of phonological information: Phonological awareness, memory and comprehension. Journal of Learning Difficulties, 39(4):325-333.

Hough S \& Home W 2001. The language transferee. Evaluators and Consultants P.O. Box 751397. Garden View 2047.

International Reading Association. (IRA) 2002. Leaders testify before reading panel. Reading Today, 16(1):1-6.

Johnson D 2006. One child at a time. Making the most of your time with struggling readers, K-6. Portland, ME: Stenhouse.

Lessing AC \& De Witt MW 2005. Teaching reading in an OBE framework. Journal for Language Teaching, 36(3):274-288.

Levin BB \& Rock TC 2003. The effect of collaborative action research on pre-service and experienced educator partners in professional development schools: Journal of Educator's professional development. Department of Education and training: Australia.

Macdonald CA 2002. Zebediela District Baseline study for the Molteno project. Unpublished research report. Johannesburg: Zenex foundation.

Ma X \& Crocker R 2007. Provincial effects on reading achievement. The Alberta Journal of Education Research, 53(2)87-109.

McCutchen D \& Gray AL 2002. Beginning literacy; links among teacher knowledge practise and student learning. Journal of learning disabilities, 36(3):230-246

Morrow W 2005. Unpublished summary on the Provincial Education conference of the Western Cape Education Department, 23-24 March.

National Literacy Trust 2006. Reading for pleasure; A research overview.

National Reading Panel 2000. Teaching children to read: An evidence-based assessment of the scientific research literature on reading and its implications for reading instruction. Washington

Ntsime JM and PAP Mampie 1988. Mathasedi: Mophato wa Ntha. Publisher: Via Africa

Pretorius EJ Machet MP 2004. The socio-educational context of literacy accomplishment in disadvantaged schools: lessons for reading in early primary school years.

Raphael TE, Pardo, LS \& Highfield K 2002. Book club: A literature-based curriculum. Lawrence, MA: Small Planet Publications. 
Read Educational Trust 2005. Clyson Printers, Braamfontein. Johannesburg.

Rose D 2006. Teacher Training Manual. Literacy Across the curriculum. Sydney. Learning to Read. Reading to Learn.

Snow CE, Dickinson DK \& Tabors PO 2002. The home-school study of language and literacy development.

Stahl KAD \& Duffy-Hester 2004. Proof, practice, and promise: Comprehension strategy instruction in the primary grades. The Reading Teacher, 57(?):598-609.

Teale WH 2003 Reading aloud to young children as a classroom instructional activity: Insights from research and practice. In A. Van Kleeck, S.A. Stahl, \& E. B. Bauer (Eds.), On reading books to children (pp 114-139). Mahwah, NJ: Lawrence Erlbaum.

The Molteno Project 2003. Impumelelo Kiwi Literacy (Breakthrough to Literacy); Teacher's Guide. Cape Town: Maskew Miller Longman. 